\title{
Literature Review : Penerapan Senam Hamil Terhadap Penurunan Nyeri Punggung Pada Ibu Hamil Trimester III
}

\author{
Much Ilham Bintara Indah ${ }^{1 *}$, Windha Widyastuti ${ }^{2}$ \\ ${ }^{1,2}$ Program Studi Diploma Tiga Keperawatan Fakultas Ilmu Kesehatan Universitas \\ Muhammadiyah Pekajangan Pekalongan, Indonesia \\ *email: fikes@umpp.ac.id
}

\begin{abstract}
Back pain is a problem commonly experienced by pregnant women in the third trimester. One of the effective ways to reduce that pain is pregnancy exercise. This scientific writing aims to describe the implementation of pregnancy exercise to pregnant women who experience back pain based on a literature review. The review was done to three articles from similar journal, which were published during 2018 - 2020. The Numeric Rating Scale (NRS) was used as the instrument. From 39 pregnant women who participated, $97.4 \%$ of them were $20-35$ years old and $69.2 \%$ were fulltime housewives. The result showed that average value of the pain scale before the intervention was 5.42 , and after the intervention was 2.70. The conclution of this literature review was that the implementation of pregnancy exercise was effective in reducing the intensity of back pain in pregnancy. Hence, health workers are supposed to encourage pregnant women to do pregnancy exercise, especially in the third trimester.
\end{abstract}

Keywords: Keywords: Pregnancy; Back Pain, Pregnancy Exercise

\begin{abstract}
Abstrak
Ketidaknyamanan nyeri punggung umum dialami oleh ibu hamil Trimester III. Salah satu tindakan untuk menurunkan nyeri punggung yang efektif adalah senam hamil. Karya Tulis Ilmiah ini bertujuan untuk menggambarkan penerapan senam hamil pada ibu hamil yang mengalami nyeri punggung berdasarkan literature review. Subyek literature review yang digunakan yaitu 3 jurnal dengan laman jurnal yang yang sama, terbit tahun (2018-2020). Instrumen pada ketiga artikel ini menggunakan NRS (Numeric Rating Scale). Hasil analisa karakteristik responden dari 3 jurnal menunjukkan dari jumlah responden 39 ibu hamil. Sebagian umur responden adalah 20-35 tahun (97,4\%), mayoritas status pekerjaan adalah IRT $(69,2 \%)$. Nilai rata-rata skala nyeri sebelum intervensi 5,42, setelah intervensi 2,70. Kesimpulkan dari literature review adalah senam hamil efektif dalam menurunkan intensitas nyeri punggung pada kehamilan. Saran bagi pelayan kesehatan hendaknya menigkatkan penerapan senam hamil kepada seluruh ibu hamil terutama trimester III.
\end{abstract}

Kata kunci: Kehamilan, Nyeri Punggung, Senam Hamil

\section{Pendahuluan}

Masa kehamilan adalah masa dimulainya dari konsepsi sampai kelahiran bayi selama 280 hari yang mulai dihitung dari hari pertama haid terakhir. Pembagian kehamilan dibagi dalam 3 trimester, yaitu trimester pertama, dimulai dari konsepsi sampai 3 bulan ( 0 -12 minggu) kemudian Trimester kedua dari bulan ke empat sampai 6 bulan (13-28 minggu) selanjutnya Trimester ketiga dari bulan ke tujuh sampai 9 bulan (29-42) minggu. Pada proses kehamilan dapat menimbulkan beberapa 


\section{Prosiding Seminar Nasional Kesehatan Lembaga Penelitian dan Pengabdian Masyarakat Universitas Muhammadiyah Pekajangan Pekalongan}

perubahan pada sistem tubuh, seperti sistem muskuloskeletal dapat menyebabkan nyeri pada daerah punggung bawah pada ibu hamil[1]

Adanya perubahan fisik pada ibu hamil menyebabkan munculnya ketidaknyamanan selama kehamilan, terutama pada ibu hamil trimester III.Keluhan yang sering dijumpai yaitu nyeri punggung. Nyeri punggung yang terjadi pada ibu hamil dipengaruhi oleh beberapa faktor yaitu perubahan postur tubuh selama kehamilan, lekukan pada tulang lumbal yang disertai pembulatan pada bahu serta dagu yang menggantung sehingga dapat menyebabkan ketidakseimbangan otot disekitar pelvis, dan tegangan tambahan dapat dirasakan diatas ligament tersebut, aktivitas selama kehamilan juga menjadi faktor terjadinya nyeri punggung selama kehamilan

Ada dua metode untuk mengatasi nyeri punggung pada ibu hamil trimester III, yaitu metode farmakologis dan metode non farmakologis. Metode farmakologis untuk mengatasi nyeri dengan skala ringan dapat menggunakanan obat analgesic nonapoioid. Metode farmakologis ini aman digunakan namun memiliki beberapa efek samping sedangkan untuk metode non faramkologis dapat seperti: hypnosisdiri, teknik distraksi, mengurangi persepsi nyeri, mandi air hangat, stimulasi masase, kompres panas atau dingin, body mekanik yang baik serta olahraga ringan (Senam Hamil). Metode ini aman diberikan pada ibu hamil karena tanpa efek samping, selain in juga lebih murah dan efisien.Senam hamil merupakan metode non farmakologi yang dapat dilakukan untuk menurunkan nyeri pada ibu hamil [1].

Senam hamil merupakan terapi latihan gerak yang diberikan pada ibu hamil untuk mempersiapkan dirinya baik secara fisik maupun mental. Senam hamil dapat menurunkan nyeri punggung bawah yang dirasakan ibu hamil karena di dalam senam hamil terdapat gerakan yang dapat memperkuat otot abdomen, membuat elastis otot dan ligamen yang ada di punggung dan relaksasi [5].

Senam hamil berfungsi untuk memperkuat stabilitas inti tubuh yang akan membantu memelihara kesehatan tulang belakang. Mempunyai kekuatan tubuh yang baik dapat meningkatkan keseimbangan dan kestabilan ibu hamil serta meminimalkan risiko trauma tulang belakang. Selain itu saat melakukan senam hamil tubuh ibu hamil akan menciptakan endorfin lebih banyak. Endorfin merupakan zat yang memiliki prinsip kerja semacam morfin yang berfungsi untuk mengatasi stress pada saat hamil dan memberikan ketenangan serta mampu untuk mengurangi nyeri seperti nyeri pada daerah punggung sehingga senam hamil dapat menurunkan tingkat nyeri punggung pada ibu hamil [3].

Berdasarkan uraian diatas penulis tertarik untuk menyusun Karya Tulis Ilmiah dengan berjudul "Literature review : Pengaruh Senam Hamil Terhadap Penurunan Nyeri Punggung Pada Ibu Hamil Trimester III".

\section{Literature Review}

Senam hamil merupakan terapi latihan gerak yang diberikan pada ibu hamil untuk mempersiapkan dirinya baik secara fisik maupun mental, senam hamil dapat menurunkan nyeri punggung bawah yang dirasakan ibu hamil karena di dalam senam hamil terdapat gerakan yang dapat memperkuat otot abdomen, membuat elastis otot 


\section{Prosiding Seminar Nasional Kesehatan Lembaga Penelitian dan Pengabdian Masyarakat Universitas Muhammadiyah Pekajangan Pekalongan}

dan ligamen yang ada di punggung dan relaksasi. Selain itu Senam hamil merupakan olahraga atau aktivitas yang dapat dilakukan oleh ibu hamil yang bertujuan untuk menjadikan otot menjadi lebih elastis dan ligament pada panggul lebih kuat, selain itu senam hamil juga bisa memperbaiki sikap tubuh, mengntrol kontraksi, relaksasi serta mampu meperbaiki tehnik pernafasan dan mengurangi keluhan akibat perubahan bentuk tubuh yang dapat menyebabkan nyeri. Senam hamil ini juga dapat meringankan keluhan nyeri punggung yang dirasakan oleh ibu hamil karena dalam senam hamil terdapat gerakan yang dapat memperkuat otot abdomen.Latihan disertai dengan pendidikan tentang bentuk tubuh selama hamil dapat mencegah dan menghilangkan nyeri punggung pada ibu hamil.Posisi dan latihan yang mengurangi bungkuk dan meningkatkan tonus otot perut, juga dapat mencegah atau menghilangkan sakit punggung bagian bawah [3].

Nyeri punggung adalah ketidaknyamanan pada ibu hamil trimester III akibat peningkatan kadar hormone relaksin sehingga dapat memberikan efek pada fleksibilitas jaringan ligament maka berdampak pada peningkatan mobilitas sendi pada pelvis. Mobilitas sendi inilah yang mengakibatkan ketidakstabilan pelvis dan spinal sehingga adanya rasa nyeri pada punggung.Selain itu penyebab meningkatnya berat badan, perubahan bentuk tubuh, riwayat nyeri punggung yang lalu dan terjadinya peregangan yang konstan [5].

\section{Metode}

Karya Tulis Ilmiah ini menggunakan metodeLiterature review. Literature review merupakan suatu metode untuk melakukan penulisan dengan cara mengkaji dan membandingkan hasil artikel sebelumnya yang telah dikumpulkan serta dengan menambahkan gambaran umum yang relevan dari para ahli. Subjek karya tulis ilmiah adalah 3 artikel penelitian dengan topik yang sama yaitu penurunan nyeri punggung terhadap ibu hamil trimester III terutama pada intervensi dan respondennya yaitu ibu hamil trimester III dengan nyeri punggung [1][2][3]. Fokus studi dalam karya tulis ilmiah ini yaitu efektifitas senam hamil terhadap nyeri punggung pada ibu hamil trimester III.

Jenis penelitian dari tiga artikel ini menggunakan desain Quasy experiment dengan menggunakan pendekatan onegroup pre-post test design namun pada penelitian ketiga menggunakan desain Quasy experiment dengan pendekatan non equivalent control group.Quasy experiment sendiri merupakan desain penelitian dengan menggunakan kelompok subjek yang telah terbentuk secara normal (teknik rumpun), sehingga sejak awal bisa saja kedua kelompok subjek telah memiliki karakteristik yang berbeda, mungkin perbedaanya bukan disebabkan oleh perlakuan tetapi oleh sejak awal kelompok awal sudah berbeda [7].

Senam hamil merupakan olahraga mulai umur kehamilan 28 minggu atau trimester III dilakukan selama 3 minggu sekali dengan sekali tindakan selama 60 menit di ruangan nyaman dan pakaian yang sesuai. Tindakan senam hamil dihentikan bila timbul keluhan dan tindakan senam hamil dilakukan sesuai intensitas senam, bertahap, serta dengan batas kemampuan.Nyeri punggung adalah rasa nyeri yang dirasakan pada punggung bawah yang sumbernya adalah tulang belakang daerah spinal 


\section{Prosiding Seminar Nasional Kesehatan \\ Lembaga Penelitian dan Pengabdian Masyarakat Universitas Muhammadiyah Pekajangan Pekalongan}

(punggung bawah), otot, saraf atau struktur lainnya disekitar daerah tersebut. Nyeri ini terasa diantara sudut iga terbawah dan lipatan bokong bawah yaitu di daerah lumbal dan sering disertai dengan perjalanan nyeri ke arah tungkai dan kaki (Andarmoyo, 2013).

\section{Hasil dan Pembahasan Hasil}

Analisa distribusi frekuensi data demografi terjabar pada tabel 4.1

Tabel 4.1 Distribusi frekuensi responden berdasarkan karakteristik demografi

\begin{tabular}{cccc}
\hline Variabel & Kategori & Frekuensi $(\mathrm{n}=39)$ & Prosentase \\
\hline Umur & $20-35$ tahun & 38 & 97,4 \\
& $<20 \&>35$ tahun & 1 & 2,6 \\
\hline Paritas & Multigravida & 33 & 84,6 \\
& Primigravida & 6 & 15,4 \\
\hline Pekerjaan & IRT & 27 orang & 69,2 \\
& Bekerja & 12 orang & 30,8 \\
\hline Pendidikan & Dasar & 13 & 33,3 \\
& Menengah & 25 & 64,10 \\
& Tinggi & 1 & 2,56 \\
\hline
\end{tabular}

Dari tabel 4.1 di atas mayoritas responden senam hamil berumur antara 20-35 tahun $(97,4)$. Jumlah paritas responden lebih banyak multigravida dengan 33 responden $(84,6)$ sedangkan primigravida 6 responden $(15,4)$. Rata-rata pekerjaan responden adalah IRT dengan 27 responden $(69,2)$ sedangakan lainnya bekerja dengan 12 rresponden $(30,8)$. Mayoritas pendidikan responden beradda pada tingkat menengah dengan presentase sebesar $64,10 \%$.

Tabel 4.2 Distribusi frekuensi nyeri punggung responden tanpa intervensi dandengan intervensi.

\begin{tabular}{ccc}
\hline Variabel & \multicolumn{2}{c}{ Nilai rata rata } \\
\cline { 2 - 3 } & Sebelum & Sesudah \\
\hline Nyeri & 5,42 & 2,70 \\
\hline
\end{tabular}

Berdasarkan tabel 4.2 di atas, kelompok ibu hamil yang mengalami nyeri punggung sebelum dan sesudah diberikan tindakan senam hamil mengalami perubahan penurunan yang signifikan yaitu dengan nilai rata-rata penurunan 2.72.

\section{Pembahasan}

Karya tulis ilmiah ini membahas tentang penurunan nyeri punggung dengn penerapan tindakan senam hamil.Hasil analisis data dari ke ketiga jurnal tersebut menunujukan rata-rata nyeri punggung dapat berkurang dengan senam hamil dengan hasil penelitian pertama $p$-value $0,00<0,05$, penelitian kedua $0,00<0,04$, penelitian ketiga $0,157>(a), 05)$ Sehingga rata-rata tingkat nyeri punggung sebelum dan 


\section{Prosiding Seminar Nasional Kesehatan Lembaga Penelitian dan Pengabdian Masyarakat Universitas Muhammadiyah Pekajangan Pekalongan}

sesudah dilakukan senam hamil mengalami penurunan. Setelah diberikan senam hamil banyak responden yang mengalami penurunan nyeri punggung secara signifikan.

Nyeri punggung disebabkan oleh beberapa faktor yaitu pertumbuhan uterus yang menyebabkan perubahan postur, penambahan berat badan, pengaruh hormon relaksin terhadap ligamen, riwayat nyeri punggung terdahulu. Pertumbuhan uterus yang sejalan dengan perkembangan kehamilan mengakibatkan teregangnya ligamen penopang 5 yang biasanya dirasakan ibu sebagai spasme menusuk yang sangat nyeri yang disebut dengan nyeri ligamen.Hal inilah yang menyebabkan nyeri punggung.Beberapa penelitian terdahulu menunjukkan bahwa tindakan yang dapat dilakukan untuk mengatasi nyeri punggung adalah senam hamil [1][2][3].

Senam hamil adalah suatu bentuk latihan guna memperkuat dan mempertahankan elastisitas otot-otot dinding perut, ligamen-ligamen, serta otot dasar panggul yang berhubungan dengan proses persalinan [4]. Latihan ini berfungsi untuk memperkuat stabilitas inti tubuh yang akan membantu memelihara kesehatan tulang belakang. Mempunyai kekuatan tubuh yang baik dapat meningkatkan keseimbangan dan kestabilan individu serta meminimalkan risiko trauma tulang belakang ataupun jatuh pada saat hamil [5]. Gerakan senam hamil dapat melatih otot perut bagian dalam yang yang memiliki fungsi utama sebagai penopang tulang punggung.Demikian pula pada gerakan dibagian otot pelvis karena dengan gerakan tersebut dapat menjadikan tonus otot lebih kuat serta meningkatkan ketahanan otot postural yang terletak pada dasar pelvis.Disamping itu dengan melakukan aktivitas senam hamil secara rutin dan teratur sangat bermanfaat untuk memperkuat otot-otot perut serta mencegah terjadinya ketegangan pada pelvis yang berlebihan sehingga mengurangi rasa tidak nyaman serta nyeri pada punggung. Kegiatan senam hamil juga mampu mengeluarkan endorphin yang berfungsi untuk memberikan rasa tenang sehingga bisa mengurangi rasa tidak nyaman dan nyeri pada punggung saat hamil [1].

Hal ini disebabkan karena ketika responden bersedia melakukan senam hamil dengan benar dan teratur sehingga tekanan pada otot punggung ataupun pergeseran pada tulang punggung menjadi berkurang. Hasil penelitian ini sejalan dengan penelitian yang dilakukan Isma'ul (2013) dengan judul Hubungan Senam Hamil Dengan Nyeri Punggung Pada Ibu Hamil Di Polindes Desa Tlanak Kecamatan Kedungpring Kabupaten Lamongan. Hasil penelitian tersebut didapatkan ibu hamil yang melakukan senam hamil secara teratur maka semakin kecil mengalami nyeri punggung.

Adapun sampel dari ketiga penelitian ini memiliki perbedaan bahwa :

\begin{tabular}{|l|l|l|}
\hline \multicolumn{1}{|c|}{ Penelitian } & \multicolumn{1}{|c|}{ Sampel } & \multicolumn{1}{c|}{ Keterangan } \\
\hline Pertama & 33 responden & Ibu hamil \\
\hline Kedua & 10 responden & Ibu hamil \\
\hline Ketiga & 20 responden & $\begin{array}{l}10 \text { orang kelompok intervensi } \\
10 \text { orang kelompok control }\end{array}$ \\
\hline
\end{tabular}




\section{Prosiding Seminar Nasional Kesehatan \\ Lembaga Penelitian dan Pengabdian Masyarakat

Grafik dari ketiga penelitan

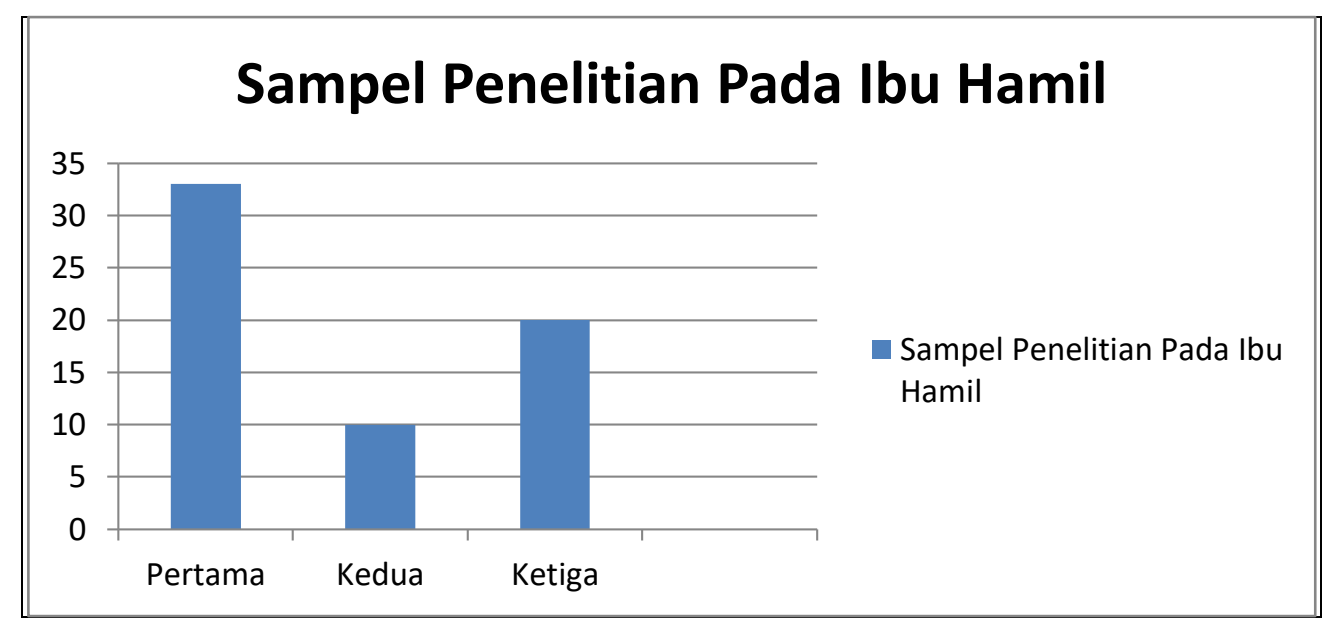

Hal ini menunjukkan penelitian kedua menggunakan sampel yang lebih kecil dibandingkan sampel pada penelitian pertama dan ketiga karena berdasarkan [7] salah satu syarat sampel harus cukup banyak, makan hasil penelitian akan lebih representatif. meskipun keseluruhan lapisan populasi telah terwakili, jika jumlahnya kurang memenuhi maka hasilnya kurang atau bahkan tidak bisa memberikan gambaran tentang popolasi yang sesungguhnya. Sebenarnya tidak ada pedoman umum yang digunakan untuk menentukan besarnya sampel untuk satu penelitian.Besar kecilnya penelitian sangan dipengaruhi oleh rancangan dan ketersediaan subjek dari penelitian itu sendiri.

Instrumen penelitian yang digunakan dalam ketiga penelitian ini adalah lembar observasi menggunakan Numeric Rating Scale (NRS).Instrumen penelitian ini terbukti valid untuk digunakan dalam mengukur nyeri punggung, contohnya skala 0-10 (skala numeric), skala deskriptif yang menggambarkan intensitas tidak nyeri sampai nyeri yang tidak tertahankan [8].Penelitian ini adalah dengan menggunakan lembar observasi. Observasi adalah proses memperoleh keterangan untuk bertujuan penelitian dengan mencatat hasil skala nyeri punggung sebelum dan sesudah dilakukan intervensi. Prosedur tindakan yang dilakukan pada penelitian pertama dan ketiga memilik persamaan yaitu dilakukan 1 bulan dengan tindakan senam hamil sebanyak 4 kali namun pada penelitian kedua tidak disebutkan, Sedangkan menurut [9] senam hamil idealnya dilakukan 3 kali seminggu/teratur.

Hasil dari ketiga penelitian tersebut dapat disimpulkan bahwa senam hamil dapat menurunkan skala nyeri punggung pada ibu hamil secara signifikan. Hasil ini sesuai dengan penelitian [10] menjelaskan bahwa terdapat pengaruh senam hamil terhadap penurunan rasa nyeri punggung pada ibu hamil trimester III dengan nilai $p$ value 0,000 $\leq$ a 0,05 . Hal tersebut sejalan dengan penelitian yang dilakukan oleh [11] yang menyatakan bahwa terdapat penurunan skala nyeri pada ibu hamil sebelum dan setelah dilakukan senam hamil dengan nilai rata-rata penurunan yaitu 26 dengan nilai p. value 0,000 yang artinya terdapat hubungan yang bermakna. Penelitian ini sejalan dengan penelitian yang dilakukan oleh [12] yang menyatakan bahwa terdapat perbedaan penurunan nyeri antara kelompok kontrol dan kelompok intervensi dengan 


\section{Prosiding Seminar Nasional Kesehatan \\ Lembaga Penelitian dan Pengabdian Masyarakat Universitas Muhammadiyah Pekajangan Pekalongan}

nilai $p$ kelompok intervensi $p=0,000$ dan nilai $p$ pada kelompok kontrol $=0,158$. Berdasarkan hasil uji statistik terdapat penurunan nyeri punggung bawah pada ibu hamil trimester III dengan nilai $p=0,000$. Hasil beberapa artikel dapat disimpulkan bahwa tindakan senam hamil sangat efektif untuk menurunkan nyeri pada ibu hamil.

\section{Kesimpulan}

Perubahan fisik pada ibu hamil menyebabkan munculnya ketidaknyamanan selama kehamilan, terutama pada ibu hamil trimester III. Keluhan yang sering dijumpai yaitu nyeri punggung..Berdasarkan analisa dari 3 artikel, penulis menyimpulkan bahwa senam hamil dapat menurunkan nyeri punggung pada ibu hamil trimester III.Senam hamil dapat menurunkan nyeri punggung bawah yang dirasakan ibu hamil karena di dalam senam hamil terdapat gerakan yang dapat memperkuat otot abdomen, membuat elastis otot dan ligamen yang ada di punggung dan relaksasi.

\section{Referensi}

[1] Wirda and Ernawati, "Efektifitas Senam Hamil Pada Ibu Hamil Trimester Iii Terhadap Penurunan Nyeri Punggung Di Desa Pa'Rapunganta Kecamatan Polongbangkeng Utara Kabupaten Takalar," J. Islam. Nurs., vol. 5, no. 1, pp. 6874, 2020.

[2] Y. Purimama, "PENGARUH SENAM HAMIL TERHADAP PENURUNAN NYERI PUNGGUNG PADA KEHAMILAN TRIMESTER III DI PUSKESMAS WATERS," Universitas 'Aisyiyah, 2018.

[3] Hamdiah, T. Tanuadike, and E. Sulfianti, "Pengaruh Senam Hamil Terhadap Nyeri Punggung Bawah Pada Ibu Hamil Trimester III di Klinik Etam Tahun 2019," Indones. J. midwifery (IJM), vol. 3, no. 1, pp. 40-45, 2020,

[4] M. Megasari, "Hubungan Senam Hamil dengan Nyeri Punggung Pada Ibu Hamil Trimester III," J. Kesehat. Komunitas, vol. 3, no. 1, pp. 17-20, 2015, doi: 10.25311/jkk.vol3.iss1.95.

[5] F. et all Yosefa, "Efektifitas senam hamil terhadap penurunan nyeri punggung pada ibu hamil," Kebidanan, vol. 1, no. 1, pp. 1-7, 2014

[6] E. E. Subroto, "visualisasi pembelajaran senam ibu hamil dengan menggunakan animasi 3 dimensi," STMIK AMIKOM YOGYAKARTA, 2014.

[7] Nursalam, Metodologi Penelitian IImu Keperawatan: Pendekatan Praktis. Jakarta: Penerbit Salemba Medika, 2017.

[8] M. Judha, Sudarti, and A. Fauziah, Teori Pengukuran NYERI dan Nyeri Persalinan, 2nd ed. YOGYAKARTA: Nuha Medika, 2014.

[9] A. Maryunani and Y. Sukaryati, Senam Hamil Senam Nifas dan Terapi Musik, Cetakan pe. Jakarta: CV. Trans Info Media, 2011.

[10] R. Anggraeni, "Pengaruh Senam Hamil Terhadap Penurunan Rasa nyeripunggung Pada Ibu Hamil Trimester Iii," Cendekia Med., vol. 3, no. 1, pp. 2620-5424, 2018. 


\section{Prosiding Seminar Nasional Kesehatan \\ Lembaga Penelitian dan Pengabdian Masyarakat Universitas Muhammadiyah Pekajangan Pekalongan}

[11] L. Fitriani, "Efektivitas Senam Hamil Dan Yoga Hamil Terhadap Penurunan Nyeri Punggung Pada Ibu Hamil Trimester III Di Puskesmas Pekkabata," J-KESMAS J. Kesehat. Masy., vol4, no2, p72, 2019, doi: 10.35329/jkesmas.v4i2.246

[12] M. Delima, Maidaliza, and N. Susanti, "Pengaruh Senam Hamil Terhadap Penurunan Tingkat Nyeri Punggung Bawah Pada Ibu Hamil Trimester II dan III," pp. 79-89, 2015. 